\title{
É muito bonito no papel, mas na realidade deixa a desejar... educação (escolar) indígena: entre leis e realidade
}

\section{Beautiful in theory, but in reality it leaves much to be desired... indigenous education (school): among laws and reality}

\section{Rosana Hass Kondo*}

SEED

\section{Letícia Fraga** $^{* *}$}

$U E P G$

Resumo: Por meio deste trabalho pretendemos proporcionar discussões que abordem os conflitos existentes entre as políticas linguísticas (CALVET, 2007) e a realidade que se coloca na construção da educação (escolar) indígena. Para tanto, trazemos dados e análises resultantes de uma pesquisa etnográfica (LÜDKE; ANDRÉ, 1986), em nível de mestrado, que se deu entre 2011 e 2012, na comunidade Guarani do Pinhalzinho, Tomazina, Paraná. Metodologicamente, a pesquisa em questão tem cunho qualitativo/ interpretativista (ANDRÉ, 1995; BARBIER, 2007; THIOLLENT, 2011). O aporte teórico que norteou este trabalho inclui os seguintes documentos/autores: Constituição Federal (BRASIL, 1988), LDB (BRASIL, 1996), Cavalvanti; Maher (1993), D’Angelis (1997), Veiga (2005), Grupioni (2006), dentre outros. Os resultados sugerem que: a) a educação (escolar) indígena possui grande influência na formação de lideres críticos e atuantes tanto na comunidade indígena quanto na sociedade não-indígena; b) falta autonomia e há verticalização das políticas educacionais, isto é, os aspectos relativos a educação não estão sendo construídos em conjunto com a comunidade; c) há ausência de formação continuada específica para professores indígenas e não-indígenas; d) as atitudes da Secretaria Estadual de Educação e de alguns professores não-indígenas a respeito de língua, cultura e identidade muitas vezes são etnocêntricas.

Palavras-chave: Educação (escolar) indígena. Formação de professor. Políticas linguísticas.

Abstract: Through this work we intend to provide discussion that address the conflicts between language policies (CALVET, 2007) and the reality placed in the construction of the indigenous education (school). To this end, we bring data and analysis resulting from an ethnographic study (LUDKE; ANDRE, 1986), made in master's degree level which happened between 2011 and 2012, in the indigenous community of Pinhalzinho, Tomazina - Parana. Methodologically, the research in question has qualitative / interpretive nature (ANDRE, 1995; BARBIER, 2007; THIOLLENT, 2011). The theoretical basis that guided this work includes

\author{
* Mestre em \\ Linguagem, Identidade \\ e Subjetividade. \\ rosanahass@gmail. \\ com \\ ** Doutora em \\ linguística. \\ leticiafraga@gmail. \\ com
}


the following documents / authors: Constituição Federal (BRASIL, 1988), LDB (BRASIL, 1996), Cavalcanti; Maher (1993), D’Angelis (1997), Veiga (2005), Grupioni (2006), among others. The results suggest that: a) indigenous education (school) has great influence in the formation of critical and active leaders in both indigenous and non-indigenous society; b) there is lack of autonomy and verticalization of educational policies, i.e., aspects relating to education are not being constructed along with the community; c) there is no specific continuing education for indigenous and non-indigenous teachers; d) the attitudes of the State Educational Department and of some non-indigenous teachers regarding the language, culture and identity are often ethnocentric.

Keywords: Indigenous education (school). Teacher education. Language policies.

\section{Introdução}

Toda sociedade tem sua forma específica de organização, de modo que a educação destinada a um povo deve refletir os desejos e anseios da comunidade em que ela se encontra inserida. Nesta direção, a expressão educação (escolar) indígena sugere que se trata de uma educação específica, para um povo específico. Essa distinção é extremamente relevante, pois evita sua generalização.

Segundo Cavalcanti e Maher (2005), qualquer pessoa que deseje ou que trabalhe com educação indígena deve ter esses conceitos bem definidos. “[...] Quando fazemos menção à "Educação Indígena”, estamos nos referindo aos processos educativos tradicionais de cada povo indígena. Aos processos nativos de socialização de suas crianças” (MAHER, 2006, p. 16-17).

Na educação indígena, segundo Maher (2006), não existe um professor específico, mas sim várias pessoas que se responsabilizam por passar para as futuras gerações seus ensinamentos e conhecimentos, valorizando sempre o bem-estar de todos. Tomando essa definição como parâmetro fica claro em quais princípios a educação para estes povos deve se pautar. Ou seja, uma educação que respeite suas formas de pensar, ver e ser no mundo. Portanto, "[...] o que se ensina na escola de uma sociedade indígena deveria ser aquilo que aquela sociedade deseja que se ensine” (D’ANGELIS, 2001, p. 36-37).

Ao falar em educação indígena também devemos considerar que ela não se restringe à escola, uma vez que esta se inicia no contexto familiar e se estende aos diversos locais, inclusive na escola.

A educação das crianças, sua socialização na comunidade, se faz na família, pelo ensinamento dos pais, pelas palavras e histórias dos mais velhos e por muitos outros meios que a comunidade possua, inclusive pela escola (ou seja, também pela escola) (D’ANGELIS, 2001, p. 37). 
Já a educação (escolar) indígena se “[...] refere ao processo de escolarização dessas crianças e desses jovens, de modo a instrumentalizá-los para situações de contato com o mundo dos brancos” (CAVALCANTI; MAHER, 2005, p. 5).

A partir do contato com o branco, no entanto, esse conhecimento [educação indígena] passou a ser insuficiente para garantir a sobrevivência, o bemestar dessas sociedades. É preciso agora também conhecer os códigos e os símbolos dos "não índios", já que estes e suas ações passaram a povoar o entorno indígena. E é assim que, historicamente, surgiu a "Educação Escolar Indígena” (MAHER, 2006, p.17, grifos da autora).

Dessa forma, a educação indígena, que até então bastava para esses povos, atualmente já não é suficiente devido ao contato contínuo com outras sociedades.

Sendo assim, nossa intenção neste artigo $^{1}$ é propor uma discussão que evidencie os conflitos existentes entre as políticas linguísticas (CALVET, 2007) e a realidade que se coloca na construção da educação (escolar) indígena.

\section{Metodologia e contexto}

Metodologicamente, esse trabalho enquadra-se na abordagem qualitativa de pesquisa (LÜDKE; ANDRÉ, 1986; ANDRÉ, 1995), também conhecida como “naturalística ou naturalista” (ANDRÉ, 1995, p. 17). No caso da pesquisa em questão, acreditamos que a escolha da pesquisa qualitativa foi mais adequada, justamente por esta permitir que a análise acontecesse a partir de um "contexto vivo", uma vez que "[a] pesquisa qualitativa procura entender, interpretar fenômenos sociais inseridos em um contexto” (BORTONI-RICARDO, 2008, p. 35).

Os dados foram coletados etnograficamente. Conforme Braz (2010, p. 41), “[a] investigação etnográfica, oriunda da antropologia, compreende o estudo do meio social pela observação direta das formas costumeiras de viver de um grupo particular de pessoas”. Ou seja, por meio desse método é possível levantar dados sociais, culturais, linguísticos de uma sociedade.

Os instrumentos utilizados para geração de dados foram: a) observações, b) entrevistas semiestruturadas e c) diário de campo. Posteriormente, os dados foram analisados qualitativamente.

A pesquisa em questão foi realizada na Comunidade Indígena do Pinhalzinho localizada a aproximadamente $36 \mathrm{~km}$ do município de Tomazina, Paraná, às margens do Rio Cinzas (PROJETO POLÍTICO PEDAGÓGICO, 2011). Esta comunidade Guarani é composta por aproximadamente 122 pessoas distribuídas em 35 famílias, compostas de indígenas “puros”" e também de “mestiços”3 devido aos casamentos com não-índios. Há presença também de duas famílias Kaingang na comunidade.
${ }^{1}$ Este texto é uma reflexão a partir de uma pesquisa de mestrado desenvolvida no programa de "Linguagem, Identidade e Subjetividade", na Universidade Estadual de Ponta Grossa (UEPG), intitulada "Representações e atitudes linguísticas na (re)construção da identidade indígena dos Guarani do Pinhalzinho (Tomazina/PR): um estudo na escola "Yvy Porã"”.

${ }^{2}$ Expressão usada pelos indígenas do Pinhalzinho para se referir aos Guarani que descendem de pai e mãe reconhecidos pela comunidade como indígenas.

${ }^{3}$ Expressão usada pelos Guarani do Pinhalzinho para se referirem aos filhos de pai ou mãe reconhecido(a) pela comunidade como indígena, com pai ou mãe não reconhecido(a) como indígena. 
Ao todo, participaram da pesquisa quatorze (14) pessoas ${ }^{4}$, as quais desempenham na comunidade e/ou escola importantes papeis, mas neste texto, por razões de escopo analisaremos somente os discursos de nove (9) participantes.

\section{A educação (escolar) indígena na prática}

As aulas observadas durante a pesquisa de campo foram fundamentais para entendermos e conhecermos alguns aspectos importantes da Pedagogia Escolar Indígena Guarani ${ }^{5}$ (NOBRE, 2009) e também para verificarmos como se dá a interação entre professores indígenas e não-indígenas, comunidade e alunos.

À primeira vista tem-se a impressão que as aulas na escola indígena pouco diferem das ministradas em contexto não-indígena, porém basta adentrar esse espaço para se percebam as diferenças. De imediato, o que mais nos chamou a atenção é a tranquilidade com que os alunos circulam nesse espaço.

Depois descobrimos que também há diferenças entre o modo como o professor indígena e não-indígena veem isso: "As crianças sentem-se à vontade para tomar qualquer decisão, como a de sair da sala da aula, se a atividade não estiver lhe interessando mais” (NOBRE, 2009, p. 36).

Um trecho do Diário de Campo confirma esses fatos:

Chego ${ }^{6}$ para mais um dia de observação. São quase duas da tarde e penso que estou atrasada, no entanto ao avistar os alunos no pátio vejo que não. Ao entrar no pátio cumprimento a todos e vou falar com o diretor, conversamos um pouco e noto que ainda há alunos no pátio. Tiro minhas conclusões "aqui também os alunos 'enrolam' para ir pra sala de sala”. Porém, à medida que faço mais observações vou percebendo que apesar de todas as leituras que tenho sobre educação indígena, elas não possibilitaram que eu abandonasse a minha visão ocidentalizada de educação. $O$ modo como eles veem a escola é diferente de nós. Não há cerimônia para uma visita dos pais, pois estes estão sempre por lá, as crianças vão ao banheiro, tomam água sempre que sentem necessidade. Fiquei assustada, quando durante uma aula o celular que ficava em cima da mesa do professor indígena tocou. Rapidamente uma aluna pegou, olhou e disse que era pra alguém de sua família e saiu correndo para levar. A professora não disse nada, continuou explicando. Alguns minutos depois a aluna retornou $e$ continuou suas atividades. Ao voltar para casa fiquei pensando que se isso tivesse acontecido em uma escola de não-índios teria sido um grande problema. Primeiro pelo celular que é proibido em sala. Segundo pelo aluno sair sem a permissão do professor. (Diário de Campo, 12 de abril de 2012).

Para os professores não-indígenas percebemos que é muito mais difícil considerar a situação descrita no trecho retirado do Diário de Campo
${ }^{4}$ Utilizamos siglas para preservar a identidade dos participantes.

\section{${ }^{5}$ Para uma maior compreensão da Pedagogia Escolar Indígena ver Nobre (2009).}

\footnotetext{
${ }^{6}$ Em todo o texto optamos por utilizar a primeira pessoa do plural, por entendermos que é uma obra realizada em conjunto (pesquisadora e orientadora). Entretanto, neste trecho, justificamos o emprego da primeira pessoa do singular por se tratar do relato da pesquisadora em campo.
} 
como "normal” e aceitável, justamente porque fomos educados dentro de um sistema que parte do princípio de que a escola é o local onde o professor ensina e o aluno aprende. Talvez por isso nós tenhamos dificuldades em compreender a relação que os Guarani têm com a escola e considerem a atitude descrita como indisciplina ${ }^{7}$.

Diferentemente do que acontece para os não-índios, para os Guarani a escola é um espaço bastante frequentado por todos, as famílias estão sempre presentes, de modo que reuniões com dias e horários marcados são totalmente dispensáveis, ou seja, nas escolas indígenas as famílias realmente pertencem à escola (ou a escola pertence às famílias?) conforme ilustra o trecho a seguir:

EP1: Os pais aqui são... NOSSA, frequentemente eles estão na escola, frequentemente eles entram ali na sala, vai assistir aula. Alguns e outros só que é devido a sua função na comunidade que não está, mas sempre. Nós somos todos uma família, então um vindo aqui, o outro já repassa. Aqui, aquela, aquela escola, aquela utopia que eles pregam, é uma gestão participativa mesmo aqui funciona, aqui dá certo, aqui são muito críticos... eles participam muito aqui mesmo. Os nossos, os indígenas daqui. (Entrevista realizada dia 16 de março de 2012).

Em relação aos conteúdos curriculares, conforme observamos no PPP (PARANÁ, 2011), eles seguem as Diretrizes Curriculares do Estado do Paraná.

Os conteúdos curriculares e metodologias são constantemente revistas e analisadas para estarem apropriadas as reais necessidades e interesses do aluno da comunidade Guarani adequando a natureza do trabalho na comunidade; Seguindo, assim as orientações do Plano Nacional da Educação (PNE), em que pesa requerer um tratamento diferenciado para a escola indígena; prever seus objetivos e metas além de formas flexíveis de organização escolar para as comunidades indígenas, bem como a necessária formação profissional dos professores, considerando as especificidades do alunado e as exigências do meio (PARANÁ, 2011, p.10).

Contudo, apesar de seguir as mesmas diretrizes das escolas nãoindígenas, o PPP (PARANÁ, 2011) estabelece determinações sobre os conteúdos curriculares e metodologias afirmando que estas devem ser adequadas às reais necessidades e interesses dos alunos indígenas. O PPP (PARANÁ, 2011) ainda menciona a necessidade de formação profissional dos professores, tendo em vista as especificidades do alunado. $\mathrm{Na}$ sequência, apresentamos relatos de dois professores não-indígenas sobre a questão da formação do professor para trabalhar em contexto indígena.

Pesquisadora: É você participou de cursos pra formação pra atuar especificamente aqui oferecidos pela SEED ou não?
${ }^{7}$ Segundo Nobre (2009), nas escolas Guarani, os alunos possuem mais liberdade, autonomia e descontração, portanto o aluno indígena pode circular livremente pelo ambiente escolar sem que isso seja visto como indisciplina. Não há o formalismo das escolas não indígenas, em que os alunos necessitam de permissão do professor para tomar qualquer decisão. "Há uma enorme liberdade exercida pelas crianças Guarani, que não são molestadas em quase nada. Só há alguma advertência quando o caso é de segurança física ou está atrapalhando muito a proposta do professor, o que é raro” (NOBRE, 2009, p. 36). 
PNI2: Somente uma vez. Só no primeiro ano que eu estava aqui em 2009, mas assim não especificamente na disciplina de arte. Foi Ensino Religioso, cosmologia Guarani, cosmologia Kaingang, né? E arte, mas assim quando chegou a vez da disciplina de Arte eu pensei que fosse uma coisa diferenciada e não. Era tudo que a gente já tinha na faculdade, né? Então quer dizer não era uma coisa específica só para indígena, para educação indígena. (Entrevista realizada dia 20 de abril de 2012).

PNI3: Não. Específico pra educação indígena não. (Entrevista realizada dia 10 de abril de 2012).

PNI4: Não, nenhuma preparação, agora com essa pós em educação no campo. Quer dizer ela não é específica para educação indígena, mas sempre alguma coisinha está sendo abordado. (Entrevista realizada dia 22 de maio de 2012).

Embora aqui só tenhamos apresentados três depoimentos, dos quatro professores não-indígenas entrevistados somente um participou de algum curso para trabalhar em escolas indígenas. Diga-se de passagem, já há algum tempo, pois conforme relata PN1 isso aconteceu "[...] Só no primeiro ano que eu estava aqui em 2009”. Isso nos permite inferir que houve formação para professores somente quando a escola indígena foi estadualizada, a partir de 2007 (PARANÁ, 2007). Entretanto, os documentos sugerem que a formação continuada seja uma constante, primeiramente porque o professor precisa sempre estar se atualizando e segundo porque o quadro de docentes está sempre se modificando.

PNI4 revela que está fazendo uma especialização em educação no campo e como ele próprio assinala, embora ela não seja específica para educação indígena, (...) sempre alguma coisinha está sendo abordado. Notamos que há preocupação por parte dos professores não-indígenas sobre a necessidade de capacitação para atuar nas escolas indígenas, assim como em outros contextos “diferentes”.

Pesquisadora: Você achava importante que tivesse uma preparação assim, por parte/ cursos...

PNI4: Eu acredito que sim. (...) Porque quando eu entrei aqui, eu tive muita dificuldade por isso. E não tem como dizer que a educação que a gente tem lá na cidade, urbanizada é igual a educação daqui, não é. Não adianta eu dizer que a mesma metodologia, a mesma didática que eu utilizo lá eu vou utilizar aqui, não é. Não é igual, né? Então eu acredito que tem que ter é, por exemplo, em termos de cultura, professor que vem trabalhar aqui acredito que ele tenha que saber um pouquinho mais. É cultura, a tradição deles, como que funciona a política, a organização realmente deles dentro da comunidade. (Entrevista realizada dia 22 de maio de 2012). 
No que se refere às dificuldades enfrentadas pelos professores nãoindígenas, estas se situam principalmente em relação ao trabalho com/ sobre cultura indígena, metodologia diferenciadas e também a questões políticas dentro da aldeia, ou seja, como devem se comportar, o que devem abordar ou não nas aulas. O discurso de PNI4 levou-nos a questionar em que sentido o trabalho do professor indígena é diferente do realizado pelo não-indígena, visto que LI é conhecedor das questões abordadas por PNI4.

Pesquisadora: $O$ senhor vê diferença assim entre professor indígena e professor branco ou não?

LI: Vê, Vê bastante. Tem vez que eu vou lá na escola, eles não sabe me receber, entendeu? Vem um pajé lá de fora de outra aldeia, eles não sabe receber, né? Quando vai na escola lá de fora ((outra aldeia indígena)), que ta lá, vamos supor lá onde tem bastante índio, eles sabe tem o canto deles, né? Pra receber, na hora de chegar eles cumprimenta de outro jeito, de outra maneira, né? Então, aqui não, aqui, né? Chega lá não fala nada (...) Faz o que tem que falar bom dia, boa tarde, e né? (...) a gente ensina o professor a falar, professor sabe isso daí. Só que nós chega lá eles num fala nada. (Entrevista realizada dia 25 de abril de 2012).

Para LI, as diferenças entre professor indígena e não-indígena são culturais, isto é, o professor indígena sabe da importância que as lideranças indígenas possuem dentro da aldeia, porque isso faz parte da cultura Guarani. Entretanto, isso não quer dizer que o docente não-indígena não o respeite, porém isto não é suficiente. É preciso que o professor não-indígena se esforce, conheça e utilize as normas determinadas pelos líderes indígenas, pois assim como a comunidade indígena está inserida dentro de uma sociedade não-indígena também necessita conhecer e respeitar as regras do mundo dos não-indígenas; os professores brancos também devem conhecer a cultura, a tradição e a organização política da aldeia, pois se o professor não-indígena está inserido dentro da aldeia terá de respeitar as convenções estipuladas pelas lideranças.

Em relação à questão do saber receber, LI está nos dizendo que bom-dia, boa-tarde são cumprimentos ocidentais, do homem branco e que eles, os Guarani, têm uma forma própria de cumprimentar, diferente, à qual os professores não-indígenas não conseguem se adequar.

Um dos membros da equipe pedagógica menciona outras questões sobre o trabalho dos professores indígenas e não-indígenas.

Pesquisadora: Em relação ao quadro docente como você vê o trabalho desenvolvido pelos professores indígenas e não-indígenas? Há diferenças?

EP2: SIM. Assim porque os não-indígenas já estão acostumados a um sistema que é este que a gente tem que seguir, porque a gente não conseguiu essa autonomia de ter um sistema diferente. Os professores indígenas, eles 
não conseguem se adaptar. O trabalho deles todos é diferente, justamente porque faz uma formação diferente, né? A gente tem o magistério indígena, lá específico, a professora indígena faz lá e é diferente do magistério que a gente tem normal aqui, né. Que você segue certinho um sistema. Lá não, lá eles adaptam o magistério ao indígena, ao docente indígena. Daí eu acho que essa é a diferença. O professor vem pra atuar na escola com a visão dele ainda né ((referindo à formação do professor indígena)). (Entrevista realizada dia 22 de março de 2012).

Novamente a questão do sistema educacional a ser seguido é mencionada, ou seja, não existe um sistema próprio para reger as escolas indígenas. Por isso, na visão de EP2 os professores não-indígenas conseguem se adaptar melhor, porque estão acostumados, é o sistema deles; ao passo que os docentes indígenas, não. Eles têm muita dificuldade em se adaptar.

Nas palavras de EP2, as diferenças entre professor indígena e não-indígena devem-se à formação que cada um teve. Na visão dela, o magistério indígena é totalmente voltado para o contexto indígena. Entretanto, este se "choca” com o sistema da escola a que o professor deve se adaptar - que engessa o trabalho do professor indígena - e também com a heterogeneidade presente nas comunidades indígenas, como por exemplo, a que diz respeito aos diferentes graus de conhecimento e uso da língua indígena por parte dos alunos. Por esses motivos, EP2 afirma que:

EP2: Na nossa realidade eu acho que NÃO, só professor indígena não daria conta, porque a gente tem (...) uma bem minoria aqui que quer uma educação aqui voltada assim, diferenciada mesmo, né? Já a maioria não, elas querem, eles querem a educação lá de fora, aqui dentro. (Entrevista realizada dia 22 de março de 2012, grifos nossos).

Pelos trechos destacados, podemos inferir que, na visão de EP2, o fato de a maioria desejar uma educação lá de fora aqui dentro é um dos motivos que impede que somente professores indígenas atuem na escola, pois conforme EP2 havia colocado anteriormente o modo como o professor trabalha está associado a sua formação. Ou seja, o professor indígena é formado para valorizar mais a língua e a cultura de sua etnia, enquanto o professor não-indígena possui outros valores que também estão associados a sua formação. Por outro lado, ao dizer que “[...] só o professor indígena não daria conta [...]” EP2 deixa claro que a presença de professores indígenas e não-indígenas permite que os alunos possam conhecer os dois lados, tendo contato tanto com a visão dos brancos quanto da sociedade indígena.

Um dos professores indígenas entrevistados revela sua opinião sobre a presença de professores não-indígenas dentro da escola.

PI1: Seria o certo, mas como os indígenas estão se preparando para atuarem nas suas próprias escolas... por enquanto temos que aceitar e respeitar 
e trocar experiências para que a escola tenha uma boa qualidade de ensino. Com o tempo com certeza teremos futuramente professores indígenas e é para isso que estão se preparando. (Entrevista realizada dia 12 de abril de 2012).

É interessante observar que PI1 considera que a presença dos professores não-indígenas na escola auxilia os professores indígenas, uma vez que aqueles assumem a maior parte das aulas nas escolas indígenas, permitindo que os professores indígenas possam se preparar para atuar nas suas próprias escolas depois de qualificados. PI1 não chega a afirmar que acredita ou mesmo quer que essa seja uma situação apenas temporária. Entretanto, enfatiza que enquanto esse contato acontecer, a convivência entre índio e não-índios também é positiva, já que permite que troca de experiências, para que a escola tenha uma boa qualidade de ensino.

Assim, com o intuito de analisarmos esses aspectos a seguir discutiremos como a educação (escolar) indígena tem acontecido na realidade. Ou seja, o que as leis (BRASIL, 1988; BRASIL, 1996) determinam tem sido cumprido?

\section{É muito bonito no papel, mas na realidade deixa a desejar...}

"Foram décadas de políticas claramente contrárias aos índios, ou ainda que favoráveis no plano de discurso e no plano legal, amplamente complacente com práticas violentas, que visavam à extinção da diferença” (GRUPIONI, 2006, p. 40). Entretanto, hoje podemos dizer que, pelo menos teoricamente, a política mudou, pois as principais leis brasileiras (BRASIL, 1988; BRASIL, 1996) possuem artigos e parágrafos que garantem aos povos indígenas direitos relativos a questões territoriais, educacionais e linguísticas, entre outros.

Por outro lado, sem querer destituir a importância que tais documentos têm para esses povos, queremos esclarecer que a contemplação dos direitos indígenas em lei não garante que, na prática, eles estejam realmente sendo resguardados, ou seja, não significa que as políticas vigentes em relação a eles deixaram de ser contrárias aos seus interesses. Nossa crítica é baseada em fatos concretos observados e registrados em campo, que mostram o descumprimento da lei em todos os sentidos. Isso inclui desde questões primárias - que vão do acesso a materiais escolares básicos - até as mais complexas, que envolvem o direito desses indígenas de participar de e decidir sobre a educação que desejam.

Entretanto, na maioria das vezes essas questões são imperceptíveis aos não-índios, pois à primeira vista tem-se a impressão de que tudo tem sido conduzido a partir de decisões tomadas pela comunidade. A gestão da escola Yvy Porã é feita por um indígena. Há também alguns professores indígenas trabalhando na escola (diga-se de passagem, em número bem 
reduzido) e os professores não-indígenas são “escolhidos” pelo Cacique, porém a participação da comunidade, sua autonomia acaba aí. Essa escolha é formalizada por meio de uma carta de autorização fornecida pelo Cacique ao professor.

De acordo com o relato de uma professora não-indígena, a partir do meio do ano a situação fica bastante complicada, pois existem muitos conflitos para se obter essa autorização (Diário de campo 23 de março de 2012). A fala do professor indígena a seguir exemplifica os conflitos vivenciados nesse período.

PI2: "[...] porque quando começa o PSS, é aquela loucura. Cada um faz sua melhor política porque que ele quer dar aula aqui dentro, né? E às vezes ( ) acaba caindo na lábia de alguns que não tem comprometimento e no decorrer do ano que a gente vai vendo quem tem comprometimento, quem não tem. Quem leva a sério de fato o ensino. (Entrevista realizada dia 02 de maio de 2012).

Segundo LI, essa postura é uma forma de tentar fazer com que os professores sejam mais comprometidos com a escola e realmente queiram trabalhar em benefício da comunidade. O excerto a seguir deixa claro os "acordos" que os professores não-indígenas tentam fazer para obter a carta de autorização.

LI: ((risos)) Tem professor que quer ficar aqui. Telefona e faz acordo, né? Começa a trazer tudo quanto é coisa que sabe? Tudo quanto é coisa de comer, é roupa, começa a comprar presente, fazendo sabe? Agrado. Aí acabou pronto, acabou, acabou também ((risos)). A gente sabe. A gente pega, sabe? ( ), mas lá dentro a gente sabe, tá sabendo como é, né? Como é que é. (Entrevista realizada dia 25 de abril de 2012).

O discurso anterior revela que o "comprometimento" de muitos professores não-indígenas acaba quando estes conseguem tal carta. Isso ficou evidente na semana pedagógica (em julho de 2012), pois conforme pudemos observar no entendimento da direção da escola Ivy Porã e também no da SEED, tal atitude deixa transparecer certo descompromisso para com a educação (escolar) indígena, já que esse seria um importante momento de discussão sobre suas especificidades.

Consideramos que este momento foi extremamente importante para a comunidade do Pinhalzinho, que há muito tempo tem conhecimento de como são pensadas e aplicadas as políticas linguísticas para os povos indígenas. Ou seja, é nítida a “voz que se ouve” (D’ANGELIS, 1997) quando se diz que há participação de indígenas na tomada de decisões relativas a questões educacionais. Fica evidente a hierarquia entre índios e não-índios, sendo que quem está na posição de poder é sempre um não-índio. Entretanto, as ações propostas para os povos indígenas são naturalizadas, isto é, a 
sensação de dominação ou subalternidade é amenizada, pois ela é disfarçada com "boas intenções". Porém, basta que se analisem mais detidamente esses discursos para que se perceba a partir de que pontos de vistas as políticas têm sido elaboradas.

\section{Uma educação verdadeiramente indígena}

O que seria uma educação verdadeiramente indígena? Seria uma escola onde somente professores indígenas atuariam como docentes? Seria uma escola com materiais didáticos elaborados para aquela realidade específica? Questionamentos como estes se fazem necessários justamente para que possamos pensar o quão complexo são os processos educacionais que envolvem a educação, principalmente quando esta é destinada a povos que possuem uma visão diferente da hegemônica sobre a importância da escola em suas vidas. Na visão da professora indígena, uma educação verdadeiramente indígena seria:

PI1: Ter material didático próprio para a formação docente e não ter o tempo limitado porque os indígenas não têm tempo programado, porque o tempo todo eles estão ocupados com seus afazeres na comunidade ou na sua casa.

Na sociedade dominante, a escola é constantemente associada ao local onde o conhecimento e a aprendizagem ocorrem de modo formal e sistemático. Entretanto, para as sociedades indígenas esse conceito é ampliado, pois a escola é vista como uma extensão onde o conhecimento também ocorre. Na fala da professora, não ter o tempo limitado, porque os indígenas não têm tempo programado, porque o tempo todo eles estão ocupados com seus afazeres na comunidade ou na sua casa reforça a ideia de que a aprendizagem extrapola a esfera escolar. A esse respeito, o professor indígena exemplifica.

PI2: O ensino, o ensino pro índio é totalmente diferente né? (...) um dia eu cheguei no seu J.((pajé)) ele falando pra mim, ensinando eu a fazer um remédio pro corte no machucado, né? E ele me ensinou e peguei lá o rubi ((erva medicinal)) com outras coisas lá e fiz e bem rapidinho, sarou. Aí eu falei: como é que o senhor sabe? Quem ensinou o senhor? Ele falou: não é ensinou. Eu via meu pai fazendo e ele falava pra eu ir buscar uma folha, mandava eu ir buscar ali, daí mandava eu ajudar a preparar aqui. Então o ensinar pro (...) índio, ao mesmo momento que ta ali aprendendo algo com os mais velhos, daqui a pouco ele ta lá, lá na frente lá aprendendo a cortar uma árvore, ao mesmo momento depois que ele saiu de lá ele ta lá com a mãe dele aprendo a ( ). Então se for pra gente ( ) até o conceito de ensinar pra nós indígenas é diferente, nós estamos tendo que se adaptar a esse modelo ocidental. (Entrevista realizada dia 02 de maio de 2012). 
É o ensino por meio de modelo, da imitação (VEIGA, 2005), o conhecimento é sempre socializado. Todavia, muitas vezes esse modo de aprender não é considerado nas escolas indígenas, justamente porque os modelos de educação destinados aos indígenas são baseados na educação do branco, já que "[t]odo o currículo é, por via de regra, feito pelo branco e transmitido pelo professor nativo, que se encarrega, então, de aplicá-lo ao aluno índio" (CAVALVANTI; MAHER, 1993, p. 219).

EP1: A burocra/ a burocracia num acompanha esse meio de ensinar do, do indígena. Na verdade... ele... ele ((referindo-se ao sistema de educação)) fala é que quer dar essa, essa abertura, no entanto, num, num consegue, por quê? Por quê? Que nem eu falei o ensinar do índio não está restrito somente às quatro horas da, na... às cinco horas das salas de aula e sim pra fora e, sim mais exteriores ainda. (Entrevista realizada dia 16 de março de 2012).

Pelas palavras de EP1, entendemos que para o indígena o conhecimento e aprendizagem também podem acontecer na escola, porém estes não ficam restritos somente à sala de aula. Outro fato que também pode ser observado na fala de EP1 é com relação ao sistema de educação imposto pela sociedade dominante. Isto é, o modelo de escola, de educação ocidental que não consegue dar conta da imensa diversidade que habita as comunidades indígenas. Esses conflitos ficam bastante evidentes no discurso anterior, pois ao mesmo tempo em que ele necessita atender as regras e normas determinadas pela SEED, também é cobrado pelas lideranças indígenas para que a escola trabalhe a língua, cultura e costumes da comunidade.

Portanto, embora a Constituição Federal (BRASIL, 1988) e a LDB (BRASIL, 1996) garantam aos povos indígenas uma educação que priorize suas formas e sistemas próprios na elaboração de uma educação própria, percebe-se que na prática tais direcionamentos não se realizam. Essa é também a percepção de um professor não-indígenas entrevistado.

Pesquisadora: E como você vê a educação (escolar) indígena no Brasil? Assim pelo que você sabe.

PNI1: Abandonada. Promessas, que vocês ((referindo-se aos indígenas)) tem isso, tem aquilo, porque como é indígena é mais fácil, mas não é. (Entrevista realizada dia 18 de abril de 2012).

O discurso de PN1 também evidencia a representação muito presente no imaginário do senso comum que acha que os indígenas possuem certa facilidade para conseguir seus objetivos ou ainda que recebem mais atenção e proteção por parte do Estado em relação aos não-indígenas.

Relatos de outros dois professores não-indígenas mostram as dificuldades enfrentadas pela comunidade indígena. 
PNI3: Abandonada, porque é o que eu tô dizendo. A gente não tem material. Sabe a... ela ((referindo-se professora da educação infantil)) mesma começou a educação infantil não tinha nada, nada de material, sabe?

(Entrevista realizada dia 10 de abril de 2012).

PNI2: É com indiferença. A gente percebe que muitas coisas/a gente percebe situação de abandono. Eles... muitas vezes, eles não dão/ não dão o devido valor, atenção que merecia ser, ser, receber, né? Que merecia receber. (Entrevista realizada dia 20 de abril de 2012).

Os termos “abandonada” e “indiferença” utilizados para definir o tratamento dado à educação (escolar) indígena só ratificam a não observação aos direitos básicos desses povos pelo poder público. Outro trecho da fala de PNI2 “[...] Eles... muitas vezes, eles não dão/ não dão o devido valor, atenção que merecia ser, ser, receber, né? Que merecia receber.” reitera a desvalorização dos povos indígenas por parte da sociedade não-indígena.

Em relação às leis destinadas aos povos indígenas, o excerto abaixo confirma que a existência da lei por si só não é suficiente.

PNI2: É muito bonito no papel, mas na realidade deixa a desejar, porque eles... a SEED, sabe? A Secretaria de Educação que é a SEED, o núcleo, tudo, eles deixam, eles se esquivam um pouco dessa parte das incumbên / das incumbências deles.

Pesquisadora: Faz de conta que não vê?

PNI2: Aham, isso acaba refletindo. Eles acham que é coisa da escola, mas isso aí, a escola depende das políticas da SEED, do núcleo, políticas nacionais mesmo... depende pra que haja um bom andamento e ter os seus direitos garantidos. (Entrevista realizada dia 20 de abril de 2012).

Ao dizer que "É muito bonito no papel, mas na realidade deixa a desejar [...]" podemos entender que a lei existe, porém não é cumprida na sua totalidade. Há um "faz de conta”, ou seja, aos olhos da sociedade que desconhece a realidade das comunidades indígenas dá-se a impressão que os indígenas reclamam sem razão, que eles têm tudo de graça e não valorizam. Entretanto, essa é uma representação que tem como objetivo desqualificar a figura dos povos indígenas, reforçando a imagem que muitos não-índios já têm de que o índio é folgado, preguiçoso, bêbado, dentre outras desqualificações.

É importante esclarecermos que a falta de material mencionada anteriormente por um dos professores (PNI3) não diz respeito somente a materiais didáticos e paradidáticos prontos, mas também a materiais que permitiriam confeccionar material pedagógico. Durante uma de nossas observações na escola, pudemos perceber essa escassez de papel, lápis de 
cor, borracha, cadernos, livros, entre outros. O relato do professor a seguir confirma essa situação:

PNI3: Nós estamos agora com um projeto de... não se chama contra turno... atividade complementar. E tá pra vir uma verba desde o ano passado, que foi o primeiro semestre, nós tivemos, né? As crianças vêm no contra turno pra essel essa atividade complementar e até agora nós estamos sem a verba pra comprar papel, giz de cera material, né? Carvão pra trabalhar. A gente trabalha com o que tem. Então, é por amor mesmo. (Entrevista realizada dia 10 de abril de 2012).

Outro exemplo que também atesta o descaso do poder público para com a escola é a falta de espaço físico desta, que possui somente três salas de aulas. Desse modo, para acomodar os alunos, é necessário dividir as salas. As aulas de língua Guarani e o projeto são realizados no pátio da escola. De acordo com a equipe pedagógica da escola, já foi formalizado há algum tempo um pedido de ampliação do espaço físico à SEED, porém esta ainda não deferiu o pedido (Diário de Campo, 16 de março de 2012).

Diante disso, vemos a necessidade de se observar que:

[...] o trabalho em educação indígena não se resolve em gabinete e tampouco numa ação exclusiva do corpo técnico e administrativo do Estado, mas precisa e ganha valor na medida em que se baseia na participação dos índios e de seus aliados (GRUPIONI, 2003, p. 150, grifos nossos).

Por isso é imperativa a participação dos povos indígenas em todos os aspectos que dizem respeito à comunidade, sejam eles de ordem política, econômica, cultural ou educacional. Portanto, o desafio do professor que trabalha em contextos indígenas é enorme, pois além das especificidades próprias da educação indígena é preciso saber lidar com as adversidades constantes.

\section{Algumas considerações}

Por meio dos dados aqui analisados concluímos que os desafios da comunidade Guarani do Pinhalzinho na construção de uma educação própria são imensos, entretanto estes parecem estar determinados a isso.

Por outro lado, apesar de toda determinação demonstrada pela comunidade percebemos a existência de inúmeros fatores que dificultam a efetivação de uma educação condizente com os desejos e necessidades desses indígenas. Uma das dificuldades encontradas é a imposição de um sistema educacional homogêneo, único que embora apregoe a autonomia para os indígenas não consegue ceder minimamente diante das exigências e necessidades da educação indígena diferenciada. Isso faz com que ressaltemos a relevância de o Estado repensar posturas, atitudes e ações 
delegadas às escolas indígenas, principalmente em relação à participação, ao envolvimento das comunidades indígenas sobre quais aspectos eles querem que sejam contemplados na educação, visto que eles são os principais interessados. A educação é algo que deve ser construído em conjunto, portanto.

Em relação aos conteúdos que devem ser ensinados ou privilegiados, não há um consenso. Por um lado, cobra-se da escola que esta empenhe todos os esforços em processos de revitalização linguística e cultural. Por outro lado, é exigido dos Guarani do Pinhalzinho que estes apresentem uma proficiência cada vez maior em língua Portuguesa para interagir com a sociedade fora da aldeia.

Essa dicotomia é também verificada dentro da aldeia, visto que há indígenas que defendem um ensino mais voltado para o fortalecimento da identidade e da cultura indígena e outros que requerem um ensino mais nos moldes ocidentais. Conforme os relatos de EP2, ambas as propostas de ensino são importantes para os povos indígenas. Ou seja, o ensino deve ser intercultural, pois para eles é tão importante conhecer e aprender sobre sua cultura quanto da sociedade não-indígena, principalmente para saber como se estabelecem as relações de poder entre as diferentes culturas, umas em relação às outras.

Imersos em todos esses conflitos estão os professores indígenas e não-indígenas, principais protagonistas a quem se atribui a responsabilidade de negociar essas relações carregadas de conflitos vivenciados cotidianamente nesses contextos. Os professores vivem mais do que ninguém isso na pele, divididos entre cumprir as determinações do sistema e atender as solicitações da comunidade indígena.

Em relação ao professor não-indígena, observamos que a falta de capacitação específica para trabalhar no contexto indígena é outro fator que tem contribuído para as dificuldades que este encontra para lidar com os alunos indígenas, principalmente no início.

PNI4: No começo estranharam, bastante. É tanto que uma vez eu fui assim, conversar com um aluno e não sei esse jeito da gente, talvez mãe ou talvez, né, estabanado, no meu caso, já levei a mão, fui abraçar, dizer e ele se retraiu, tipo é você lá e eu aqui, viu? Mas agora não. Agora já brinco com eles, eles brincam comigo, sabe, já tá mais... o entrosamento já tá melhor. Mas eu sinto que precisa ainda de um passo adiante em relação a isso, porque eles têm um pouquinho de receio sim. (Entrevista realizada dia 02 de julho de 2012).

A respeito dessa questão especificamente EP1 já havia nos falado, em sua entrevista, quando afirmou que o aluno indígena demora a adquirir confiança no professor branco. No entanto, essa situação tem sido constante, pois devido aos contratos temporários o quadro docente está 
sempre sendo modificado. Este é outro problema mencionado por EP1, pois quando o aluno e também o professor estão se habituando um ao outro e também ao sistema, o professor não-indígena vai pra outra escola. Por outro lado, com o professor indígena isso é mais difícil de acontecer, pois em geral ele faz parte da comunidade indígena e, por essa razão, conhece seus problemas e dificuldades de modo mais aprofundado. No entanto, a vantagem da presença do docente indígena extrapola essas questões de conhecer os problemas da comunidade, visto que o principal benefício diz respeito ao fato de que o professor indígena é conhecedor da Pedagogia Escolar Indígena Guarani, a qual se refere aos modos apropriados de ensinar e aprender desses povos indígenas.

Segundo Nobre (2009, p. 36), a Pedagogia Indígena constitui-se de “[...] elementos autenticamente Guarani, incorporados, ressignificados, transformados no cotidiano da sala de aula”. Ainda de acordo com Nobre (2009, p.36-47), a Pedagogia Escolar Indígena Guarani é formada por onze elementos:

1. Autonomia, liberdade e descontração das crianças;

2. Forte participação das crianças;

3. Grande curiosidade e observação;

4. O Guarani como língua de instrução: bilinguismo de manutenção de resistência;

5. Forte presença da oralidade com um certo desapego à escrita;

6. Necessidade de preservação da cultura o "Nhande reko”;

7. Presenças de ritual e formalismo nas aulas;

8. Ocorrência de imitação;

9. Ocorrência de repetição nas atividades;

10. Grande respeito mútuo nas relações.

11. Grande ocorrência de desenho nas atividades.

Talvez muitos desses problemas pudessem ser resolvidos se houvesse formação continuada para esses educadores, pois conforme observamos cada um tem procurado fazer o seu melhor, porém não existe apoio realmente efetivo por parte da Secretaria Estadual de Educação. O que é real é a mobilização por parte dos próprios professores indígenas e não-indígenas e da comunidade na busca da tão sonhada educação diferenciada, específica, bilíngue e intercultural (RCNEI, 1998) que, por enquanto, só existe no papel.

Em consonância ao exposto, Nobre (2009) ressalta a importância de 
formação continuada para que realmente haja possibilidade de construir uma escola diferenciada.

Primeiramente é necessário investir na formação continuada dos educadores indígenas, pois serão eles os atores desse processo de construção curricular. Este currículo ainda não existe, ele está por ser construído para cada etnia em cada aldeia. O currículo que existe é o das escolas não-indígenas, que é tomado como referência tanto pelas assessorias como pelos educadores indígenas, que estudaram nessas escolas. Não haveria possibilidade, portanto, de construir um currículo diferenciado autenticamente indígena, ou em outras palavras, não haveria uma escola indígena "pura”. É uma utopia, no sentido de não poder ser construída, já que o currículo escolar é um construto não-indígena (NOBRE, 2009, p.13).

Entretanto, embora tenhamos apontados vários empecilhos na construção de uma educação de fato indígena e ainda haja um longo percurso a ser percorrido, a julgar pelos depoimentos e observações realizadas, acreditamos que eles estejam cada vez mais participativos e críticos nas questões que envolvem tanto a educação (escolar) indígena quanto os direitos indígenas.

\section{Referências}

ANDRÉ, M. E. D. A. Etnografia da prática escolar. Campinas: Papirus, 1995.

BARBIER, R. A pesquisa-ação. Brasília: Liber Livro Editora, 2007.

BRASIL. LEI N. 9394 de 20 de dezembro de 1996. Brasília, 1996.

Disponível em: http://portal.mec.gov.br/arquivos/pdf/ldb.pdf. Acesso em: 16 fev. 2011.

BRASIL. Constituição da República Federativa do Brasil. Diário Oficial da União, Brasília, 1988.

BRAZ, E. S. Línguas e identidades em contexto de fronteira Brasil / Venezuela. 2010, 120f. Dissertação (Mestrado em Linguística Aplicada). Instituto de Estudos da Linguagem, Campinas, SP, 2010. Disponível em: http://url20.ca/8J. Acesso em: 15 abr. 2011.

BORTONI-RICARDO, S. M. O professor pesquisador: introdução à pesquisa qualitativa. São Paulo: Parábola editorial, 2008.

CALVET, J. L. As políticas linguísticas. Tradução de Isabel Oliveira Duarte; Jonas Tenfen; Marcos Bagno. São Paulo: Parábola, 2007.

CAVALCANTI, M. C.; MAHER, T. M. Interação transcultural na formação do professor índio. In: SEKI, L. (Org.) Linguística indígena e educação na América Latina. Campinas, SP: Editora da Unicamp, 1993. 
CAVALCANTI, M. C.; MAHER, T. M. O índio, a leitura e a escrita. $\mathbf{O}$ que está em jogo? Cefiel - Centro de Formação Continuada de Professores do Instituto de Estudos da Linguagem (IEL), setembro de 2005.

D’ANGELIS, W. R. Limites e possibilidades da autonomia de escolas indígenas. In: VEIGA, J.; D’ANGELIS, W. R. (Org.) Leitura e escrita em escolas indígenas: encontro de educação indígena no $10^{\circ}$ COLE- 1995. Campinas, SP: ALB: Mercado das Letras, 1997. p. 155-165

D’ANGELIS, W. R. A educação escolar em novos contextos políticos e culturais. In: VEIGA, Juracilda; S. A. (Org.) Questões de educação escolar indígena: da formação do professor ao projeto da escola. Brasília: FUNAI/DEDOC. Campinas/ALB. 2001. p. 113-125.

GRUPIONI, L. D. B. A Educação Indígena na Academia: inventário comentado de dissertações e teses sobre educação escolar indígena no Brasil (1978-2002). Em Aberto, Brasília, v. 20, n. 76, p. 197-238, fev. 2003. http://www.rbep.inep.gov.br/index.php/emaberto/article/ viewFile/1155/1054. Acesso em: 03 jan. 2011.

GRUPIONI, L. D. B. (org.). Contextualizando o campo da formação de professores indígenas no Brasil. In: GRUPIONI, L. D. B. (org.) Formação de professores indígenas: repensando trajetórias. Brasília: Ministério da Educação, Secretaria de Educação Continuada, Alfabetização e Diversidade, 2006. p. 39-68.

LÜDKE, M.; ANDRÉ, M. E. D. A. Pesquisa em educação: abordagens qualitativas. São Paulo: E.P.U., 1986.

MAHER, T. M. Formação de Professores Indígenas: uma discussão introdutória. In: GRUPIONI, L. D. B. (Org.) Formação de professores indígenas: repensando trajetórias. Brasília: Ministério da Educação, Secretaria de Educação Continuada, Alfabetização e Diversidade, 2006. p. $11-38$.

MAHER, T. M. O Bilinguismo e o Aluno Indígena. In: $6^{\circ}$ Encontro sobre Leitura e Escrita em Sociedades Indígenas: Desafios Atuais da Educação Escolar Indígena, 2005, Campinas. Anais... Campinas: ALB/ Núcleo de Cultura Indígena, 2005. p. 97-107.

NOBRE, D. Uma pedagogia indígena Guarani na escola, pra quê? Campinas: Curt Nimuendajú, 2009.

PARANÁ. Secretaria de Estado da Educação. Superintendência de Desenvolvimento Educacional. Diretoria de Administração Escolar. Coordenação de Estrutura e Funcionamento. Instrução No 11/2007-DAE/ SUDE/SEED, que diz respeito à "Estadualização dos Estabelecimentos de Ensino Indígenas”. Disponível em: http://www.educacao.pr.gov.br/ arquivos/File/instrucoes/instrucao112007.pdf. Acesso em: 15 Abr. 2014. 
PARANÁ. Projeto político pedagógico. Tomazina: Escola Estadual Yvy Porã - Distrito Sapé, 2011.

THIOLlENT, M. Metodologia da pesquisa-ação. São Paulo: Cortez, 2011.

VEIGA, J. Pedagogia indígena e o processo de escolarização: o caso Kaingang. In: VEIGA, J.; F. M. B. R. (Org.). Desafios atuais da educação escolar indígena. Campinas/ALB, 2005. p.138-141.

Data de submissão: 29/04/2014

Data de aprovação: 11/06/2014 